\title{
TRISSOPLAX TUBEROSA CASTRO \& NG, 2010 (BRACHYURA, GONEPLACOIDEA), A NEW SOUTHERN TAIWAN RECORD OF THE RARE EURYPLACID CRAB
}

BY

\author{
PETER K. L. NG ${ }^{1}$ ) and C.-W. LIN $^{2,3}$ ) \\ 1) Lee Kong Chian Natural History Museum, 2 Conservatory Drive, National University of \\ Singapore, Singapore 117377, Republic of Singapore \\ 2 ) National Museum of Marine Biology and Aquarium, 2 Houwan Road, Checheng, Pingtung, \\ Taiwan 944, Taiwan, R.O.C.
}

\begin{abstract}
The rare euryplacid crab, Trissoplax tuberosa Castro \& Ng, 2010 is recorded from Taiwan for the first time and the known range of this species is extended to the southern part of the island. The female characters of the species are also described for the first time and are compared with those of its congener, $T$. dentata (Stimpson, 1858).
\end{abstract}

Key words. - Euryplacidae, Trissoplax, taxonomy, female characters, Taiwan

\section{RÉSUMÉ}

Le crabe rare Euryplacidae, Trissoplax tuberosa Castro \& Ng, 2010 est identifié de Taïwan pour la première fois et l'aire de répartition de cette espèce est étendue jusqu'à la partie Sud de l'île. Les caractères femelles de l'espèce sont aussi décrits pour la première fois et sont comparés à ceux de son congénère, T. dentata (Stimpson, 1858).

Mots clés. - Euryplacidae, Trissoplax, taxonomie, caractères femelles, Taïwan

\section{INTRODUCTION}

Four species of euryplacid crabs, all from the genus Eucrate De Haan, 1835, are known from Taiwan: E. alcocki Serène, in Serène \& Lohavanijaya, 1973, E. crenata (De Haan, 1835), E. formosensis Sakai, 1974, and E. solaris Yang \& Sun, 1979 (see Ng et al., 2017). Castro \& Ng (2010) revised the taxonomy of

3 ) Corresponding author; e-mail: linchiawei@nmmba.gov.tw

(C) The authors, 2018 
the Euryplacidae and showed that old records of Eucrate affinis Haswell, 1881, and Pilumnoplax sulcatifrons Stimpson, 1858, from Taiwan by Hsueh \& Huang (2002) and Wang et al. (2013) are referable to E. crenata instead.

We record Trissoplax tuberosa Castro \& Ng, 2010, from southern Taiwan, which extends the range of this species northwards. The terminology used follows Castro \& Ng (2010) and Davie et al. (2015). Measurements, in millimetres, are of the carapace width and length, respectively. Material examined is deposited in the National Museum of Marine Biology and Aquarium (NMMB), Taiwan; and Muséum national d'Histoire naturelle (MNHN), Paris.

\section{TAXONOMY}

\section{Family EURYPLACIDAE Stimpson, 1871}

Genus Trissoplax Castro \& Ng, 2010

Type species.- Heteroplax dentata Stimpson, 1858, by original designation. Remarks.- Castro \& Ng (2010) established Trissoplax for two species, $T$. dentata (Stimpson, 1858) (type species) and T. tuberosa Castro \& Ng, 2010. Trissoplax tuberosa can easily be distinguished by the absence of a tomentum on the dorsal surfaces of the chelipeds, an entire suborbital margin, the absence of an inner suborbital tooth and median lobe, and the presence of spherical tubercles on the outer surface of the chela.

\section{Trissoplax tuberosa Castro \& Ng, 2010}

(figs. 1, 2)

?Heteroplax dentatus; Serène \& Lohavanijaya, 1973: 72 [in key], 73, 98, figs. 178-182, pl. 17 [not Trissoplax dentata (Stimpson, 1858)].

Heteroplax nitidas [sic]; Serène \& Soh, 1976: 23 (part) [not Henicoplax nitida (Miers, 1879)]. Trissoplax tuberosa Castro \& Ng, 2010: 104, figs. 42A-E, 43D-F.

Material examined.- Holotype, male $(10.2 \times 7.6 \mathrm{~mm})(\mathrm{MNHN}-\mathrm{B} 10340)$, station D1, in sand with mixed dead shells and dead corals, Tanjung Ani, Piru Bay, $3^{\circ} 14^{\prime} 50^{\prime \prime} \mathrm{S} 128^{\circ} 04^{\prime} 20^{\prime \prime} \mathrm{E}$, Ceram, Moluccas, Indonesia, coll. "Rumphius 1" Expedition, 23 January 1973; 1 ovigerous female $(11.2 \times$ $8.0 \mathrm{~mm}$ ) (NMMB-CD-4088), Taiwan Kezailiao fishing port, southern Taiwan, coll. C.-W. Lin, 22 October 2014.

Remarks.- The present female specimen of T. tuberosa agrees well with the type description, and is very similar to the holotype male except that its anterolateral margin is slightly different. The external orbital tooth is relatively more truncate, with the first lateral tooth more triangular (fig. 1B) (external orbital tooth more triangular and the first lateral tooth relatively broader in the type; fig. 1C). These characters can easily be explained by the relatively large size of 


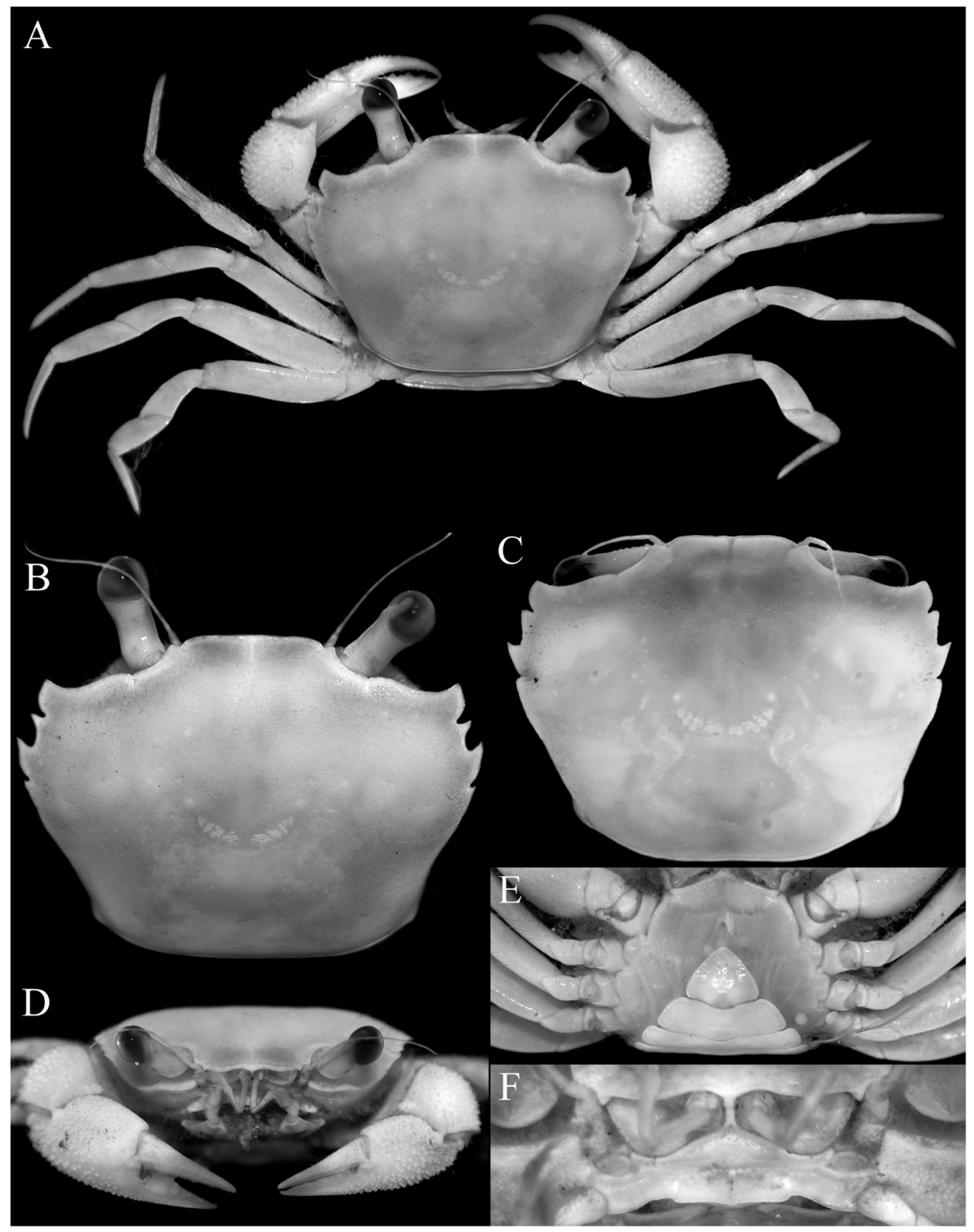

Fig. 1. Trissoplax tuberosa Castro \& Ng, 2010. A, B, D-F, female $(11.2 \times 8.0 \mathrm{~mm})(\mathrm{NMMB}-\mathrm{CD}-$ 4088), Taiwan; C, holotype male $(10.2 \times 7.6 \mathrm{~mm})(\mathrm{MNHN}-\mathrm{B} 10340)$, Indonesia. A, overall view; $\mathrm{B}, \mathrm{C}$, dorsal view of carapace; $\mathrm{D}$, frontal view of cephalothorax; $\mathrm{E}$, ventral view of cephalothorax showing pleon; F, epistome, antennules and antennae. 


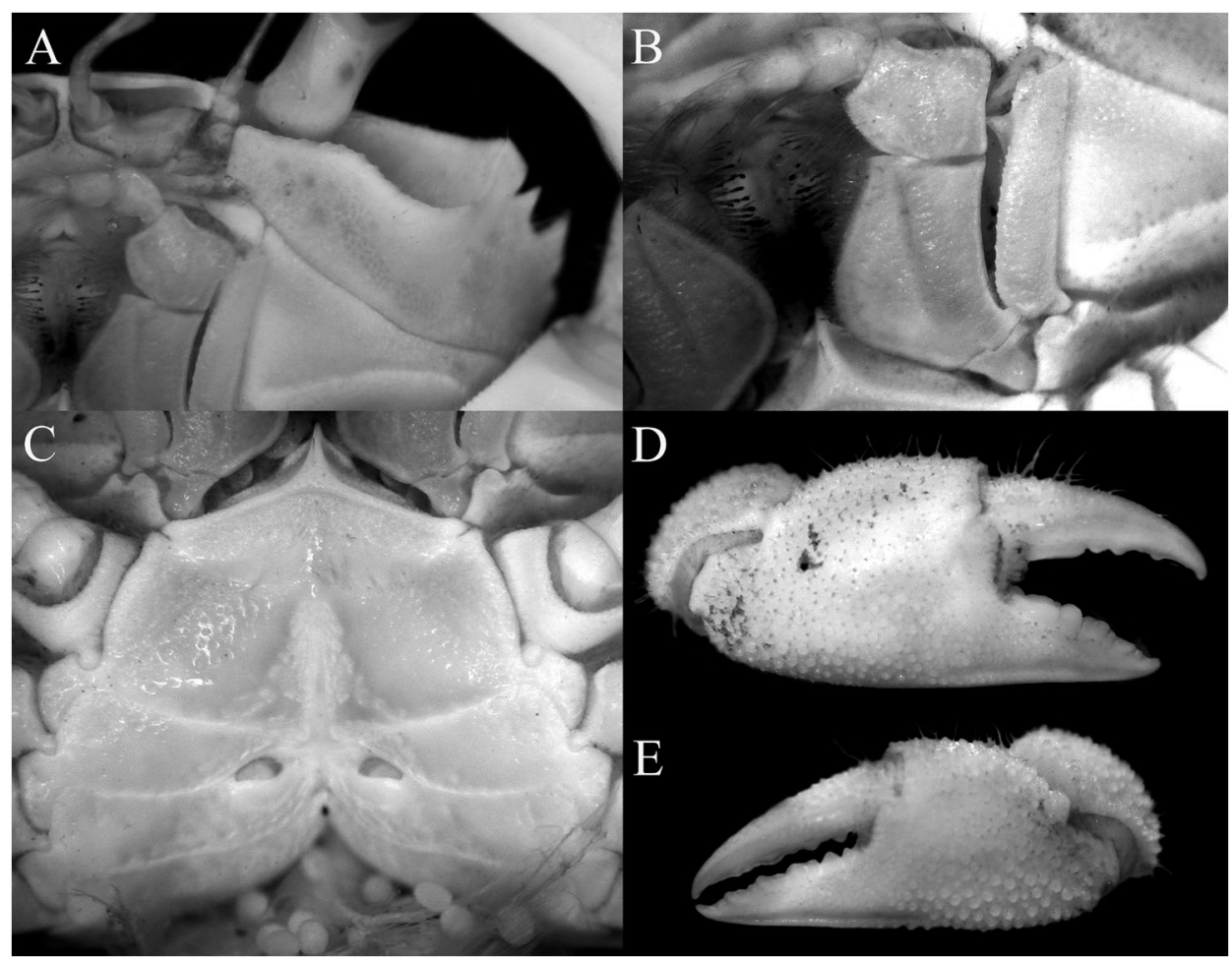

Fig. 2. Trissoplax tuberosa Castro \& Ng, 2010, female $(11.2 \times 8.0 \mathrm{~mm})$ (NMMB-CD-4088), Taiwan. A, sub-orbital and pterygostomial regions and orbit; B, left third maxilliped; C, thoracic sternum showing vulvae; $\mathrm{D}$, outer view of right major chela; $\mathrm{E}$, outer view of left minor chela.

our specimen and/or variation. The form of the anterolateral teeth is known to vary in T. dentata (cf. Castro \& Ng, 2010: 100-101).

The present specimen is useful as it is a female and permits us to describe its vulvae. The vulvae of T. tuberosa on thoracic sternite 6 are subovate, large, without an operculum and extend transversely across the anterior portion, adjacent to the margin of the suture between sternites 5 and 6 (fig. 2C). In T. dentata, the vulva has a distinct cover (Castro \& Ng, 2010, fig. 41G).

The specimen is ovigerous, indicating that it is an adult; specimens of T. dentata the size of T. tuberosa are all still juveniles (cf. Castro \& $\mathrm{Ng}, 2010$ ).

Trissoplax tuberosa was described from the Moluccas in Indonesia (Castro \& $\mathrm{Ng}, 2010$ ) and has also been recorded from the Philippines (Serène \& Lohavanijaya, 1973) and the Andaman Sea in Thailand (Serène \& Soh, 1976). Castro \& Ng (2010) noted that the type material was obtained from a depth of $15 \mathrm{~m}$. The present specimen was obtained from trawling in a muddy bottom from $100 \mathrm{~m}$. 
The live colour of $T$. tuberosa is similar to that of $T$. dentata, with a reddishbrown frontal band, brown dots on the carapace and chelae, and unevenly reddishbrown banded legs (cf. Castro \& Ng, 2010, fig. 39D-F).

\section{REFERENCES}

CAstro, P. \& P. K. L. NG, 2010. Revision of the family Euryplacidae Stimpson, 1871 (Crustacea: Decapoda: Brachyura: Goneplacoidea). Zootaxa, 2375: 1-130.

DAVIE, P. J. F., D. Guinot \& P. K. L. NG, 2015. Anatomy and functional morphology of Brachyura. In: P. Castro, P. J. F. Davie, D. Guinot, F. R. Schram \& J. C. von Vaupel Klein (eds.), Treatise on zoology — anatomy, taxonomy, biology. The Crustacea, 9(C, Decapoda: Brachyura, I): 11-163. (Brill, Leiden).

HSUEH, P.-W. \& J.-F. HUANG, 2002. Crabs of the family Goneplacidae (Decapoda, Brachyura) from Taiwan. Crustaceana, 75: 111-136.

Miers, E. J., 1879. On a collection of Crustacea made by Capt. H.C. St. John, R.N., in the Corean and Japanese seas. Proceedings of the Zoological Society of London, 1879: 18-61, pls. 1-3.

NG, P. K. L., H.-T. SHih, P.-H. Ho \& C.-H. WANG, 2017. An updated annotated checklist of brachyuran crabs from Taiwan (Crustacea: Decapoda). Journal of the National Taiwan Museum, 70(3-4): 1-185.

SERÈnE, R. \& P. LohaVAniJAYA, 1973. The Brachyura (Crustacea: Decapoda) collected by the Naga Expedition, including a review of the Homolidae. In: E. BRINTON, W. A. NEWMAN \& W. S. Wooster (eds.), Scientific results of marine investigations of the South China Sea and the gulf of Thailand, 1959-1961. Naga Report, 4(4): 1-187.

SERÈnE, R. \& C. L. SoH, 1976. Brachyura collected during the Thai-Danish expedition (1966). Research Bulletin Phuket Marine Biological Center (Thailand), 12: 1-37, figs. 1-28, pls. 1-7.

Stimpson, W., 1858. Crustacea Ocypodoidea. Prodromus descriptionis animalium evertebratorum, quae in Expeditione ad Oceanum Pacificum Septentrionalem, a Republica Federata missa, Cadwaladaro Ringgold et Johanne Rodgers ducibus, observavit et descripsit W. Stimpson, Pars V. Proceedings of the Academy of Natural Sciences of Philadelphia, 1858(10): 93-110 (39-56 in separate).

WAnG, T.-W., T.-Y. Chan, C.-W. HuAnG \& B. K. K. Chan, 2013. Thirty years of changes in the decapod community from the deep-water fishing grounds off Kueishan Island, Taiwan. Crustaceana, 86: 1382-1409.

First received 15 May 2018.

Final version accepted 21 May 2018. 